\title{
IS THERE SOLIDARITY ON ASYLUM AND MIGRATION IN THE EU?
}

\author{
Iris Goldner Lang*
}

\begin{abstract}
Summary: Solidarity is one of the core values of the European Union and has been recognised as a guiding principle of the EU asylum policy since the coming into force of the Treaty of Amsterdam. It is now incorporated into Article $80 \mathrm{TFEU}$, which provides that EU policies on border checks, asylum and immigration must be 'governed by the principle of solidarity and fair sharing of responsibility, including its financial implications, between the Member States'. The need for solidarity in the area of asylum and migration stems from the fact that some Member States have more asylum seekers than others, some have more refugees than others, and some have more difficulties in coping with them for a number of geographic, economic and other reasons. A range of measures could be used to support the functioning of solidarity, such as: financial assistance, practical cooperation, relocation, resettlement, and joint processing. This paper will discuss the potentials and (limited) progress in applying some of these measures. It will start by discussing Member States' obligations towards refugees under international and EU asylum law. The discussion will then move on to identifying the meaning of solidarity, its value in practice and Member States' motivations for establishing solidarity mechanisms. Potential differences between solidarity, burden-sharing and responsibility-sharing will also be considered. Divergent perspectives on the solidarity existing in different Member States with and without external borders will also be taken into account. The paper will conclude by discussing potential prospects on solidarity in the context of the problematic relation between the Dublin 'state of first entry' rule and the application of the principle of solidarity.
\end{abstract}

\section{Introduction}

The functioning of the EU internal market involves the abolishment of internal frontiers between Member States in order to enable free movement. ${ }^{1}$ The elimination of internal borders between EU Member States has been one of the greatest achievements of the European Union. Howe-

\footnotetext{
Jean Monnet Professor, Department of European Public Law, Faculty of Law, University of Zagreb.

1 See Art 26 TFEU.
} 
ver, removing the internal border controls for persons is closely linked with the need to harmonise Member States' rules on asylum, immigration and external border controls. ${ }^{2}$ On the other hand, the creation of a common asylum and migration policy - which aims to prevent a Member States' race to the bottom, by protecting human rights standards and by restraining national measures and policies that would deter refugees and asylum-seekers from third countries - should go hand in hand with a functioning burden-sharing mechanism. Such a mechanism would diminish reasons for (re)imposing harmful unilateral national measures and make the commonly agreed system sustainable even for the most pressured Member States. Such a system - where all the Member States are expected to abide by the common rules and standards in the area of asylum and migration, while certain Member States, particularly those creating the Union's external borders, can be expected to be exposed to a higher number of migrants, refugees and asylum seekers - needs to be based on solidarity between all the Member States.

The principle of solidarity in EU asylum and migration law has many facets. For the purpose of this paper, the following four are identified: loyalty, trust, fairness and necessity. On the one hand, solidarity involves Member States' loyalty in fulfilling the obligations arising from their EU membership. ${ }^{3}$ All Member States have committed themselves to adhere to EU primary and secondary law and properly implement Union policies. This obligation includes both Member States exposed to more and those exposed to fewer external pressures. On the other hand, solidarity is the expression of trust between Member States which have abolished internal borders among themselves. Thirdly, solidarity involves the willingness of those Member States exposed to a lower number of migrants, refugees and asylum seekers to assist the ones in need of help and support, primarily those forming the external Union border. In this context, the meaning of solidarity can be associated to 'fairness', as the Dublin Regulation enables a Member State to return an asylum seeker to the Member State which the asylum seeker first entered, as the state responsible for the examination of the asylum claim. This rule increases the uneven distribution of asylum seekers as it creates much more pressure on the Union's external borders, while relieving the Member States with no such borders. Finally, solidarity can be associated with necessity. By helping Member States in need, other Member States work towards a more secure and stable Union. Therefore, one can claim that the role of solidarity is to act as a joint insurance policy mechanism which increases the stability of the EU as a whole. Out of these four facets of solidarity,

\footnotetext{
2 See Art 67(2) TFEU; Case C-378/97 Criminal proceedings v Florus Ariël Wijsenbeek [1999] ECR I-06207, para 40.

3 The principle of loyal or sincere cooperation as stipulated by Art 4(3) TEU.
} 
some seem to be strongly present, while others are seriously lacking. So, if we define solidarity as mutual trust, then it is currently missing. On the other hand, if we define it as necessity and a legal obligation stemming from the principle of sincere cooperation, it exists, at least to a certain extent. Generally speaking, the underlying idea of solidarity is to provide a common and fundamental rights compliant mechanism which is able to respond to all the migratory and asylum-related pressures in all EU Member States, also at times of global crises and increased migratory flows.

This paper will address solidarity in the area of EU asylum and migration law. It will start by discussing Member States' obligations towards refugees under international and EU asylum law. It will try to identify the meaning of solidarity, its value in practice and Member States' motivations for establishing solidarity mechanisms. Potential differences between solidarity, burden-sharing and responsibility-sharing will also be considered. The paper will analyse different solidarity tools and instruments, such as financial assistance, practical cooperation, relocation, resettlement, and joint processing. It will discuss the degree to which different instruments oblige EU Member States to assume each others' responsibilities, and will explore the potentials and (limited) progress in applying some of these measures. Divergent perspectives on solidarity existing in different Member States with and without external borders will also be taken into account. The concluding part will discuss potential views on solidarity in the context of the problematic relation between the Dublin 'state of first entry' rule and the application of the principle of solidarity.

\section{Responsibilities towards refugees under international and EU law}

The obligations of EU Member States towards refugees stem both from EU law and a number of international conventions which have been signed by all the Member States. The 1951 Convention Relating to the Status of Refugees is the most important international document relevant for refugee law. ${ }^{4}$ Under its Article $1 \mathrm{~A}(2)$, the term 'refugee' applies to any person who

...owing to a well-founded fear of being persecuted for reasons of race, religion, nationality, membership of a particular social group or political opinion, is outside the country of his nationality and is unable or, owing to such fear, is unwilling to avail himself of the protection of that country...

4 Convention Relating to the Status of Refugees (adopted 28 July 1951, entered into force 22 April 1954) 189 UNTS 137 (1951 Convention); Protocol Relating to the Status of Refugees (adopted 31 November 1967, entered into force 4 October 1967) 606 UNTS 267.

5 For a detailed account of the refugee definition, see Andrew Shacknove, 'Who Is a Refu- 
No state may expel or return (refouler) a refugee 'to the frontiers of territories where his life or freedom would be threatened' on these grounds. ${ }^{6}$ The 1951 Convention also defines the economic, social and political rights of refugees. EU Member States' responsibilities set by the 1951 Convention stem from both the Convention itself and Article 78 TFEU which requires the EU asylum policy to be in accordance with the Convention and other relevant treaties'. Furthermore, the Convention against Torture explicitly prohibits refoulement that could lead to torture by stipulating that no state shall expel, return (refouler) or extradite a person to another state "where there are substantial grounds for believing that he would be in danger of being subjected to torture'. ${ }^{7}$ The implementation of the CAT is examined and supervised by the Committee against Torture, a body established under Article 17 of the CAT. Finally, the International Covenant on Civil and Political Rights implicitly prohibits refoulement where there is fear of torture, cruel, inhuman or degrading treatment or punishment by declaring that "no one shall be subjected to torture or to cruel, inhuman or degrading treatment or punishment'. ${ }^{8}$ The ICCPR is monitored by the Human Rights Committee.

The European Convention on Human Rights also implicitly prohibits refoulement by stating that "no one shall be subjected to torture or to inhuman or degrading treatment or punishment'. ${ }^{9}$ Accordingly, the ECtHR has in a number of cases held that states cannot deport or extradite persons who might be subject to torture, inhuman or degrading treatment or punishment. In its landmark ruling Soering v UK, the ECtHR established that extradition of a German national to the USA to face capital punishment violated Article 3 ECHR due to the likelihood of the feared exposure of the applicant to the 'death row phenomenon'. The ECtHR thus concluded that an extradition decision can engage the responsibility of the extraditing state "where substantial grounds have been shown for believing that the person concerned, if extradited, faces a real risk of being subjected to torture or to inhuman or degrading treatment or punishment in the requesting country'. ${ }^{10}$ A number of other cases followed, such as Chahal $v$ UK (a deportation order to India of a Sikh separatist on grounds of national security), ${ }^{11}$ Jabari $v$ Turkey (a deportation order of Ms Jabari to Iran which created a real risk of subjecting her to death by

gee?' (1985) 95(2) Ethics 274; James Hathaway, The Law of Refugee Status (Butterworths 1991).

6 Art 33(1) of the 1951 Convention.

7 Convention Against Torture and Other Cruel, Inhuman or Degrading Treatment or Punishment (10 December 1984, entered into force 26 June 1987) 1465 UNTS 85 (CAT) art 3(1).

8 International Covenant on Civil and Political Rights (adopted 19 December 1966, entered into force 23 March 1976) 999 UNTS 171 (ICCPR) art 7.

9 Art 3 ECHR.

10 Soering $v$ United Kingdom App no 14038/88 (ECtHR, 7 July 1989) para 91.

11 Chahal $v$ United Kingdom, App no 22414/93 (ECtHR, 15 November 1996). 
stoning), ${ }^{12}$ YP and LP $v$ France (the deportation of an opponent of the regime and his family to Belarus) ${ }^{13}$ and Hirsi (Somali and Eritrean migrants who had been travelling from Libya and were intercepted at sea by the Italian authorities and sent back to Libya, thus violating Article 3 as they faced a risk of being arbitrarily returned to their countries of origin). ${ }^{14}$

In the context of EU law, EU Member States decided to create a Common European Asylum System (CEAS) that would reduce the large differences between their asylum systems and practices and establish common minimum standards for asylum. By 2005, a number of legislative acts were adopted within CEAS, the most important being three directives and a regulation: the Reception Conditions Directive,${ }^{15}$ the Qualification Directive,${ }^{16}$ the Asylum Procedures Directive, ${ }^{17}$ and the Dublin Regulation. ${ }^{18}$

EU rules in these legal acts mostly reflect the obligations set by the 1951 Convention, but also enable more favourable national provisions. ${ }^{19}$ The possibility of applying more favourable standards is thus invoked in the three EU legislative acts on asylum adopted by 2005: Article 4 of the Reception Conditions Directive, Article 3 of the Qualification Directive and Article 5 of the Asylum Procedures Directive. Directive 2003/9 on reception conditions of asylum seekers (Reception Conditions Directive) lays down minimum standards and conditions of reception of asylum seekers and is mostly concerned with their social rights as it deals with issues such as welfare and employment. The 2004/83 Qualification Directive sets the conditions for the qualification and status of third-country nationals and stateless persons as refugees or as persons who otherwise need international protection. Directive 2004/83 has been amended by Directive 2011/9520 which will repeal Directive 2004/83 and has to be

\footnotetext{
12 Jabariv Turkey, App no 40035/98 (ECtHR, 11 July 2000).

13 YP and LP $v$ France, App no 32476/06 (ECtHR, 2 September 2010).

14 Hirsi Jamaa and Others $v$ Italy, App no 27765/09 (ECtHR, 23 February 2012).

15 Council Directive 2003/9/EC of 27 January 2003 laying down minimum standards for the reception of asylum seekers [2003] OJ L31/18.

16 Council Directive 2004/83/EC of 29 April 2004 on minimum standards for the qualification and status of third country nationals and stateless persons as refugees or as persons who otherwise need international protection and the content of the protection granted [2004] OJ L304/12.

17 Council Directive 2005/85/EC of 1 December 2005 on minimum standards on procedures in Member States for granting and withdrawing refugee status [2005] OJ L326/13.

18 Council Regulation (EC) 343/2003 of 18 February 2003 establishing the criteria and mechanisms for determining the member state responsible for examining an asylum application lodged in one of the member states by a third-country national [2003] OJ L50.

19 For the relation between EU and international asylum law, see Hemme Battjes, European Asylum Law and International Law (Martinus Nijhoff 2006).

20 Council and Parliament Directive 2011/95/EU of 13 December 2011 on standards for the qualification of third-country nationals or stateless persons as beneficiaries of international protection, for a uniform status for refugees or for persons eligible for subsidiary pro-
} 
transposed into national law by 21 December 2013. The 2005/85/EC Asylum Procedures Directive establishes minimum standards on procedures for granting and withdrawing refugee status in EU Member States. Finally, the Dublin II Regulation establishes the criteria and mechanisms for determining the Member State responsible for examining the asylum application. It is based on the principle that only one Member State is responsible for examining an asylum application. In practice, this is usually the state first entered which, in effect, shifts the responsibility to the Member States which form the southern and eastern borders of the EU with third countries. The Regulation has been heavily criticised and recent developments, culminating in the MSS judgment of the ECtHR and the NS judgment of the Court of Justice of the European Union, have revealed serious deficiencies in the system.

Even though proposals to revise all four acts have existed since 2008, only the revision of the Qualification Directive has been adopted so far, while all the other amended proposals are still in the pipeline. The proposals are said to address the deficiencies in the existing acts and do present an improvement of the current standards, but are criticised for leaving a number of issues vague and for satisfying only a rather low level of protection of fundamental rights instead of aiming for higher standards. The Proposal to recast the Reception Conditions Directive is thus viewed as a 'missed opportunity' by those advocating more dignified and fairer treatment of asylum seekers. ${ }^{21}$ On the other hand, the Recast Qualification Directive and the Proposal to recast the Asylum Procedures Directive, ${ }^{22}$ even though viewed as a significant step forward, are considered to leave certain standards vague or unsatisfactory. ${ }^{23}$ The fact that the proposed Dublin III Regulation ${ }^{24}$ maintains the underlying principles of Dublin II, which has proved to have 'extensive detrimental effects to Member States and asylum seekers' and will not address those deficiencies, has been heavily criticised by ECRE as 'not defensible'. ECRE has

tection, and for the content of the protection granted [2011] OJ L337 (Recast Qualification Directive).

21 Steve Peers, 'Analysis: The EU Directive on Reception Conditions: A Weak Compromise' 2012 Statewatch.

22 European Council on Refugees and Exiles, 'Comment from the European Council on Refugees and Exiles on the European Commission Proposal to recast the Asylum Procedures Directive' (May 2010).

23 European Council on Refugees and Exiles, 'Comments from the European Council on Refugees and Exiles on the European Commission Proposal to recast the Qualification Directive' (March 2010).

24 Commission (EC), 'Proposal for a Regulation of the European Parliament and of the Council establishing the criteria and mechanisms for determining the Member State responsible for examining an application for international protection lodged in one of the Member States by a third-country national or a stateless person' COM (2008) 820 final, 3 December 2012 (Draft Dublin III Regulation). 
further contended that 'an alternate system based on integration accompanied by substantial solidarity measures is the only way to ensure a fair, efficient and humane CEAS'. ${ }^{25}$

\section{Solidarity and responsibility-sharing in EU law}

The term 'solidarity' among EU Member States does not have a single, uniform meaning in EU law, but can refer to a number of different legal contexts. ${ }^{26}$ Solidarity among EU Member States is mentioned in the Treaties in a number of instances and within different policy areas. It is referred to as one of the values the European Union is founded on ${ }^{27}$ and as one of its principles which guides the Union's action on the international scene. ${ }^{28}$ It is also mentioned in the context of the Union's external action as 'mutual political solidarity among Member States'29 and 'a spirit of mutual solidarity'. ${ }^{30}$ Furthermore, the 'spirit of solidarity between Member States' is addressed in the case of a shortage of supply of certain products, notably energy. In the context of energy, 'a spirit of solidarity between Member States' is invoked as regards the need to preserve and improve the environment in the internal market. The principle of solidarity has its strongest expression in the 'solidarity clause' which creates the legal basis for the Union and its Member States to 'act jointly in a spirit of solidarity if a Member State is the object of a terrorist attack or the victim of a natural or man-made disaster'. ${ }^{31}$ However, apart from being one of the guiding principles in relations between EU Member States, the need for solidarity is also emphasised between generations. ${ }^{32}$ Furthermore, the need for financial solidarity or the fact that there is none has been brought up in recent political speeches in the context of the EU financial crisis, ${ }^{33}$ and by the Court of Justice ${ }^{34}$ a number of times.

\footnotetext{
25 European Council on Refugees and Exiles, 'Comment from the European Council on Refugees and Exiles on the European Commission Proposal to recast the Dublin Regulation' (April 2009).

26 For identifying the role of solidarity in different areas of EU law, see Malcolm Ross, 'Solidarity: A New Constitutional Paradigm for the EU?' in Malcolm Ross and Yuri BorgmannPrebil (eds), Promoting Solidarity in the European Union (Oxford University Press, 2010) 23-45.

27 Art 2 TEU.

28 Art 21 TEU.

29 Art 24(2) TEU.

30 Art 31 TEU.

31 Art 222 TFEU.

32 Art 3(3) TEU.

33 See for example, Sara Eisen, Interview with Jose Manuel Barosso, European Commission President, 12 April 2013 <http://www.bloomberg.com/video/-more-solidarity-forcyprus-needed-barroso-says-bJq0 hQmRjWpqTZhHcMcqw.html> accessed 15 April 2012.

34 For example, Case C-184/99 Rudy Grzelczyk $v$ Centre public d'aide sociale d'OttigniesLouvain-la-Neuve [2001] ECR I-06193, para 44.
} 
In the area of asylum, migration and border controls, Treaty articles explicitly rely on the principle of solidarity and responsibility-sharing. However, solidarity has been referred to in a number of other EU documents, some preceding the Lisbon Treaty, such as the 1999 Tampere Conclusions, ${ }^{35}$ the 2004 Hague Programme, ${ }^{36}$ the 2008 European Pact on Immigration and Asylum ${ }^{37}$ and the 2010 Stockholm Programme. ${ }^{38}$ Article 80 TFEU is the most explicit formulation of the principle of solidarity. However, the 'principle of sincere cooperation' laid out in Article 4(3) TEU and invoked by the Court of Justice on a number of occasions ${ }^{39}$ also has important implications in the area of asylum, immigration and border control, as it obliges EU Member States to 'assist each other in carrying out tasks which flow from the Treaties'. This means that the EU and its Member States are obliged to help and support each other in matters related to asylum, migration and border controls.

In Title V on the Area of Freedom, Security and Justice, solidarity is first mentioned in Article 67 as the opening provision. Article 67(2) TFEU invokes 'solidarity between Member States, which is fair towards thirdcountry nationals', as the basis for framing a common policy on asylum, immigration and external border control. Article 80 TFEU, as the central and most specific call for solidarity in Title V, stipulates:

The policies of the Union set out in this Chapter and their implementation shall be governed by the principle of solidarity and fair sharing of responsibility, including its financial implications, between the Member States. Whenever necessary, the Union acts adopted pursuant to this Chapter shall contain appropriate measures to give effect to this principle.

Explicit reference to 'solidarity' and 'fair sharing of responsibility' in Article 80 TFEU covers all policies on border checks, asylum and immigration. Article 80 TFEU has thus extended the application of these principles from asylum only, as first stipulated by the Amsterdam Treaty in Article 63(2)(b)TEC, to border policy and migration. Therefore, solidarity should be the guiding principle throughout all the policy areas covered by Chapter II of the TFEU. Furthermore, reference to solidarity when drafting and implementing all the policies on border checks, asylum and immigration shows the intention to apply this principle not only in emergency situations, such as a mass inflow of refugees, but also

\footnotetext{
35 Council, 'Presidency Conclusions' (Tampere, 15-16 October 1999).

36 Council, 'Presidency Conclusions: The Hague Programme for Strengthening Freedom, Security and Justice in the European Union' (Brussels, 4-5 November 2004).

37 Council, 'European Pact on Immigration and Asylum' (Brussels, 24 September 2008).

38 Council, 'The Stockholm Programme - An Open and Secure Europe Serving and Protecting Citizens, European Council' [2010] OJ C-115/1.

39 See, for example, Case C-61/11 PPU Hassen El Dridi, alias Karim Soufi [2011] ECR I-03015.
} 
when shaping these policies. However, it is questionable whether Article 80 TFEU has direct effect, as it can only become effective once certain legislative and policy measures have been taken. ${ }^{40}$

Solidarity applies both to EU institutions and the Member States. However, measuring solidarity and fair sharing of responsibility is not an easy task. The Treaty provides no specification to help determine what constitutes these terms. Their goals or the benchmarks to measure their fulfilment are undefined. In this respect, the interests of EU institutions do not necessarily match those of EU Member States, while the interests of the Member States also frequently diverge. Responsibility-sharing can be seen as one of the manifestations of the principle of solidarity, implying a fair distribution of burdens, consequent to EU borders, immigration and asylum policies, among EU Member States. The fact that Article 80 TFEU explicitly refers to the 'financial implications' of solidarity, but does not limit itself only to this manifestation of burden-sharing (as implied by the phrase 'including its financial implications'), suggests the importance of financial burden-sharing, but also calls for other forms of cooperation among Member States that could lead to burden-shifting to Member States under less pressure. ${ }^{41}$

Member States' motivation for solidarity in the area of asylum and migration might vary. States that are geographically exposed to a disproportionate number of refugees call for burden-sharing with other, less pressured Member States. Their reasons for urging for solidarity are primarily financial, social and political. On the other hand, another type of self-interest might encourage other Member States to assist and participate in the burden-sharing mechanisms. This is primarily the reasoning that a joint insurance policy would increase stability and security and reduce the possibility of unexpected calamities and harmful unilateral actions of those Member States primarily hit by refugees. ${ }^{42}$ The potential of unexpected increases in the number of refugees and asylum seekers in one Member State, induced by external factors, can encourage Member States to see the advantages and agree to burden-sharing mechanisms. This is well illustrated by the example of Austria which had 6,724 asylum

\footnotetext{
40 Cf Wijsenbeek (n 2) para 40 where the Court of Justice stated that then art 7a TEC [now art 26 TFEU] does not have direct effect as it "presupposes harmonisation of the laws of the Member States governing the crossing of the external borders of the Community, immigration, the grant of visas, asylum and the exchange of information on those questions'.

41 For burden-sharing, see Eiko Thielemann, 'Between Interests and Norms: Explaining Burden-Sharing in the European Union' (2003) 16(3) Journal of Refugee Studies 253; Eiko Thielemann, 'Towards Refugee Burden-Sharing in the European Union State Interests and Policy Options' (Ninth Biennial International Conference of the European Union Studies Association, Austin, 31 March-2 April 2005); Rosemary Byrne, 'Harmonization and Burden Distribution in the Two Europes' (2003) 16(3) Journal of Refugee Studies 336.

42 See Astri Suhrke, 'Burden-Sharing during Refugee Emergencies: The Logic of Collective versus National Action' (1998) 11(4) Journal of Refugee Studies 396.
} 
applications in 1985, compared to 27,306 asylum applications in 1991 7,506 of those coming from Romania and 6,436 from former Yugoslavia (due to the armed conflict there). The number again fell drastically to 4,745 in 1993, again rising to 39,355 in $2002 .{ }^{43}$

The ability of one Member State to effectively handle immigrants, refugees and asylum seekers, while preserving human rights standards, might have positive consequences for all the other Member States, as it reduces irregular migration and increases internal security. The entry of a high number of migrants, refugees and asylum seekers into one Member State might have serious consequences for its neighbours, as was vividly shown in the case of the Franco-Italian affair of spring 2011 when hundreds of North African immigrants from Tunisia came to Italy and were issued with resident permits for humanitarian reasons, allowing them to exercise an automatic right of freedom of movement to other Member States. The French authorities reacted by reintroducing border controls on the Franco-Italian border, by blocking trains and sending the incoming immigrants back to the Italian territory. ${ }^{44}$

\section{Solidarity tools and instruments}

Several tools and instruments have been developed and could be employed for the purpose of enabling and promoting solidarity and burden-sharing in the area of asylum and migration. Some of these tools provide for financial assistance (such as the European Refugee Fund), while others enable assistance in kind (such as relocation and resettlement). Some of them have, to a higher or lesser degree, already been employed, while others are still unrealised ideas put on the table for the future, such as joint processing. Despite the fact that there is (still) no consensus as to what joint processing would be, in its March 2012 Conclusions, the Council invited the Commission to prepare a study on the feasibility of joint processing of asylum claims and to report its finding to the Member States. ${ }^{45}$

\footnotetext{
43 Eurostat asylum statistics, 'Asylum Applications' <http://epp.eurostat.ec.europa.eu/ $\operatorname{tgm} /$ table.do?tab=table\&plugin=0\&language $=$ en\&pcode=tps00021 $>$ accessed 15 April 2012; Migration Policy Institute (MPI) Data Hub, 'Country and Comparative Data' < http://www. migrationinformation.org/GlobalData/countrydata/data.cfm> accessed 15 April 2012.

44 For an account of the whole affair, which was characterised as a 'race to the bottom on European principles of solidarity, loyalty and fundamental rights', see Sergio Carrera and others, 'A Race against Solidarity: The Schengen Regime and the Franco-Italian Affair' (2011) CEPS Liberty and Security in Europe Working Paper April 2011, 1; Sergio Carrera, 'An Assessment of the Commission's 2011 Schengen Governance Package: Preventing Abuse by EU Member States of Freedom of Movement?' (2012) CEPS Liberty and Security in Europe Working Paper March 2012, 1.

45 See Council, 'Council Conclusions on a Common Framework for genuine and practical solidarity towards Member States facing particular pressures on their asylum systems,
} 
Even though financial support is not the only solidarity instrument, it is the most important and effective one for assisting Member States in need of help. A number of financial instruments promote solidarity, the European Refugee Fund being the longest standing one and covering asylum procedures, reception infrastructure, integration of refugees, resettlement and emergency measures. There are currently four funds allocating almost EUR 4 billion under the Framework Programme 'Solidarity and the Management of Migration Flows for the period 2007-2013': the European Refugee Fund (EUR 700 million), the European Borders Fund (EUR 1,820 million), the European Return Fund (EUR 630 million) and the European Fund for the Integration of Third-Country Nationals (EUR 825 million). However, they all seem to have in common the lack of adequate resources and over-bureaucratic procedures. They are, therefore, more motivational than compensatory. ${ }^{46}$ The next Multiannual Financial Framework for 2014-2020 should reduce the number of programmes to two funds: the Asylum and Migration Fund (EUR 3,869 billion) and the Internal Security Fund (EUR 4,648 billion). With an overall budget of EUR 10.9 billion, the total home affairs budget for the 2014-2020 period should exceed the 2007-2013 period by 40\%. The Asylum and Migration Fund will focus on the integrated management of migration, thus covering all aspects of migration including asylum, legal migration, integration and the return of irregularly staying non-EU nationals. On the other hand, the Internal Security Fund will concentrate on the implementation of the Internal Security Strategy and deal with the management of the Union's external borders.

Intra-EU relocation is another method of assisting Member States exposed to disproportionate external pressures. However, previous practice has shown that, despite its generally positive impact, intra-EU relocation is highly limited in scope and based on a political, voluntary decision. Its impact is restricted to emergency situations and cases of Member States' exposure to a disproportionate number of refugees exceeding their capacities. It is primarily aimed at refugees and persons under subsidiary protection and not at asylum seekers. Relocation should, therefore, not be considered as an improvement or compensation of the Dublin Regulation. The European Commission's study of relocation has shown that a number of EU Member States preferred other burden-sharing tools, such as policy harmonisation as well as technical and financi-

including through mixed migration flows', Brussels, 8 March 2012; Commission, 'Communication from the Commission to the European Parliament, the Council, the European Economic and Social Committee and the Committee of the Regions on enhanced intra-EU solidarity in the field of asylum - An EU Agenda for better responsibility-sharing and more mutual trust' COM (2011) 835 final.

46 European Parliament Study, 'What System of Burden-sharing Between Member States for the Reception of Asylum Seekers?' January 2010, PE 419.620. 
al assistance, to relocation. ${ }^{47}$ Furthermore, half of the Member States in the study were against relocating asylum seekers. This view corresponds with the Dublin 'state of first entry' rule which sets limits to relocation.

So far, intra-EU relocation has been taking place from Malta within the framework of a European Refugee Fund-funded pilot project EUREMA (phases I and II). Malta, being the smallest EU Member State, has been exposed to a disproportionate number of refugees. On the other hand, its reception conditions have been reported as poor, as has its progress with the local integration of newly arrived third-country nationals. Given this situation, the EU Home Affairs Commissioner appealed to other Member States' solidarity which resulted in the decision of twelve Member States to participate in the EUREMA pilot project, while eight Member States and associated countries decided to make bilateral arrangements with Malta. The objective was to show solidarity with Malta by relocating 255 individuals in need. Despite the project's general success, evaluation has shown that the selection criteria were sometimes too demanding, while there was a lack of harmonisation as regards the status granted by the participating states. ${ }^{48}$

Finally, intra-EU relocation should not be confused with the resettlement of refugees from third countries. Resettlement is defined as the 'transfer of refugees from a state in which they have sought asylum to a third state that has previously agreed to admit them as refugees and grant them a form of legal status, with the possibility of acquiring future citizenship'. ${ }^{49}$ Unfortunately, despite increasing worldwide needs for resettlement, the EU Member States are not taking the lead and helping people in need. Based on the ECRE data, in 2011, the EU collectively resettled 4,325 refugees amounting to only $7 \%$ of the global total that year (61,649 departures).

\section{Conclusion}

Solidarity is one of the core values of the European Union and has been recognised as a guiding principle of the EU asylum, migration and border control policies. However, studies have shown that in these areas of EU law there is little agreement as to the exact meaning and scope of the term 'solidarity', although there seems to be common understanding

\footnotetext{
47 European Commission, 'Study on the Feasibility of Establishing a Mechanism for the Relocation of Beneficiaries of International Protection', July 2010, JLS/2009/ERFX/PR/ 1005 2010-70092056.

48 European Asylum Support Office, 'EASO Fact Finding on Intra-EU Relocation Activities from Malta' (July 2012) <http://easo.europa.eu/wp-content/uploads/EUREMA-fact-finding-report-EASO11.pdf $>$ accessed 26 October 2013.

49 European Asylum Support Office, 'Resettlement'<http://www.ecre.org/topics/areas-ofwork/resettlement.html> accessed 26 October 2013.
} 
that solidarity is important for the functioning of these policy areas. ${ }^{50}$ The Dublin Regulation, with its 'state of first entry' criterion as decisive for determining the Member State responsible for examining the asylum application, creates a burden-shifting rather than a burden-sharing mechanism. The Dublin system has been heavily criticised as unsustainable and undermining asylum seekers' fundamental rights. Its successful implementation relies on the condition that Member States provide for an equal level of protection based on their substantive and procedural rules. The Dublin criteria are based on the Member States' mutual trust in the adequate level of quality and efficiency of each other's asylum system. However, several studies, including the UNHCR one, have highlighted divergent practices among Member States and revealed highly different recognition rates for the same profile of asylum seekers. ${ }^{51}$ It is questionable whether the Draft Dublin III Regulation will resolve the open issues and ambiguities in terms of allocating responsibility and ensuring protection of individuals in need. The Dublin mechanism cannot properly function in the event of an unfair or incomplete examination of asylum applications in some Member States, inadequate access to legal remedies and legal representation, and inappropriate detention conditions.

However, despite inadequate conditions in certain Member States, particularly Greece, up to the MSS judgment of the ECtHR and the NS judgment of the Court of Justice of the European Union in 2011, Member States were unwilling to suspend transfers to Greece. They were reluctant to rely on the 'suspension clause' contained in Article 3(2) of the Dublin Regulation, presuming that the other Member State was a safe country. The $N S^{52}$ and $M S S^{53}$ judgments emphasise that asylum seekers must not be transferred to a Member State whose asylum system manifests systematic deficiencies.

The Draft Dublin III Regulation, if adopted, would provide for a temporary suspension of transfers for six months, extendable once by six months, if decided by the Commission and not overruled by the Council. ${ }^{54}$ However, the underlying rationale of the Dublin II Regulation would not be changed, as the responsibility for examining the asylum application would still lie "primarily with the Member State which played the

\footnotetext{
50 See European Parliament Study, "The Implementation of Article 80 TFEU on the Principle of Solidarity and Fair Sharing of Responsibility, Including its Financial Implications, Between Member States in the Field of Border Checks, Asylum and Immigration' April 2011, PE 453.167.

51 See UNCHR, 'The Dublin II Regulation - A UNHCR Discussion Paper' (April 2006).

52 Joined cases C-411/10 and C-493/10, NS $v$ Secretary of State for the Home Department and $M E$ and Others $v$ Refugee Applications Commissioner and Minister for Justice, Equality and Law (ECR, 21 December 2011).

53 MSS v Belgium and Greece App no 30696/09 (ECtHR, 21 January 2011).

54 Art 31 of the Draft Dublin III Regulation.
} 
greatest part in the applicant's entry into or residence on the territories of the Member States, subject to exceptions designed to protect family unity'. The Draft foresees the role of the European Asylum Support Office (EASO) as providing practical assistance and expertise to Member States in taking decisions on asylum applications and to Member States under disproportionate external pressure. EASO should provide an 'early warning, preparedness and crisis management mechanism' which should prevent Member States' systematic deficiencies before they escalate into a crisis.

It remains questionable whether functioning solidarity is compatible with the underlying principle of the Dublin 'state of first entry' rule in the case of the absence of an EU-wide efficient and human-rights compliant system. The current system, of inadequate financial assistance and ad hoc responses to emergency situations through intra-EU relocation, is insufficient to respond to the challenges ahead. Future EU asylum and migration policy should involve a higher degree of solidarity between Member States, expressed not only through ad hoc measures, but also through systematic responsibility-sharing. EASO should play a key role in this context, while new instruments such as joint processing, in addition to financial solidarity, should also be considered. 